\title{
The Post-Development Dictionary agenda: Paths to the pluriverse
}

Federico Demaria, Institute of Environmental Science and Technology, Universitat Autònoma de Barcelona (Spain) and Research \& Degrowth

and

Ashish Kothari, Kalpavriksh (India) and ICCA Consortium

\section{Federico Demaria}

Position: Researcher

Affiliation: Research \& Degrowth, Institute of Environmental Science and Technology, Autonomous University of Barcelona

Address: Edifici Z, ICTA-ICP; Carrer de les Columnes, Campus de la UAB; 08193 Bellaterra (Cerdanyola del Vallès); Barcelona, Spain.

Tel. 0034622135090

Email: federico.demaria@uab.cat

\section{Ashish Kothari}

Coordinator, Alternatives

Kalpavriksh - Environmental Action Group

Apt 5 Shree Datta Krupa, 908 Deccan Gymkhana, Pune 411004, India

Tel. 0091-20-25675450

chikikothari@gmail.com

Keywords: well-being, sustainability, degrowth, buen vivir, ecofeminism, transition, socioecological transformation

\footnotetext{
Abstract

This article lays out both the critique of the oxymoron sustainable development, as well as the potential and nuances of a post-development agenda. We present Ecological Swaraj from India and Degrowth from Europe as two examples of alternatives to development. This gives a hint for the forthcoming book, The Post-Development Dictionary that is meant to deepen and widen a research, dialogue and action agenda for activists, policy makers and scholars on a variety of worldviews and practices relating to our collective search for an ecologically wise and socially just world. Such a volume could be one base in the search for alternatives to United Nations' 2030 Agenda for
} 
Sustainable Development, in an attempt to truly 'transforming the world'. In fact, it is an agenda towards the pluriverse: 'a world where many worlds fit', as the Zapatista say.

\section{Introduction}

2017 marks the $25^{\text {th }}$ anniversary of The Development Dictionary edited by Wolfgang Sachs. ${ }^{\mathrm{i}}$ While the Dictionary might have fallen short of its intention to write the obituary of development, it did send shock waves through the activist, policy, and scholarly worlds and became an influential text. The relevance and impact of Sachs' book is still felt today. At the same time, there is no dearth of newly revitalized hegemonic notions, of which 'the green economy' might be best known, with the 'amoeba concept' (meaning its high malleability) of sustainable development still floating ${ }^{1}$, and indeed given new life by the global intergovernmental agreement on Sustainable Development Goals in 2015. In this context, we are working on a volume that while emulating the spirit of the original Dictionary, brings both reincarnated worldviews and fresh alternatives to 'development' sharply into view. The starting point is the need to go beyond critique and concentrate efforts on articulating the narratives of those struggling to retain or create diverse ways of life against the homogenising forces of development. There is a need for radical post-development practices, ideas, and worldviews to become an agenda for activists, policy makers and scholars, to help in truly 'transforming our world', and therefore be an alternative to the 2030 Agenda for Sustainable Development. ${ }^{\text {ii }}$

The concept of "Post-Development" emerges from the confluence of four main books: First, The Development Dictionary edited by Wolfgang Sachs; Second, Encountering Development by Arturo Escobar; Third, The History of Development by Gilbert Rist; Fourth, The Post-Development Reader edited by Rahnema and Bawtree. ${ }^{\text {iii }}$ Two decades later, our book, The Post-Development Dictionary focuses more upon alternatives to, rather than the critique of, development.

Post-development is generally meant as an era or approach in which development would no longer be the central organizing principle of social life. Even as critiques of development increase in academic spaces, they are equally powerfully arising amongst indigenous peoples, other local communities, womens' rights movements, and other civil society; most prominently amongst the victims of development. Across the world this is resulting in the resurfacing of ancient worldviews with current relevance, or new frameworks and visions that present systemic alternatives for human

1 Words like 'development' or 'strategy' have been called 'amoeba concept' or 'plastic words' because of their malleability and the uncanny way they are used to fit every circumstance (Poerksen, 2004). Like plastic Lego blocks, they are combinable and interchangeable. In the mouths of experts-politicians, professors, corporate officials, and planners - they are used over and over again to explain and justify any type of plans and projects. 
and planetary well-being. It is also forcing the decolonization of knowledge systems and epistemologies, breaking down many of the dualisms that western patriarchal paradigms have engendered, such as between humans and nature.

Post-development is related to at least three other emerging imaginaries, that of postcapitalism (questioning capitalism's ability to fully and naturally occupy the economy, with the concomitant visualization of an array of diverse economic practices), post- or de-growth (decentring growth from the definition of both the economy and social life) and post-patriarchy (challenging the primacy of masculinist approaches to political leadership, moral authority, social privilege and control of property). The current mood is "to search for alternatives in a deeper sense, that is, aiming to break away from the cultural and ideological bases of development, bringing forth other imaginaries, goals, and practices"iv

Therefore, we argue that the time is ripe to deepen and widen a research, dialogue and action agenda on a variety of worldviews and practices relating to our collective search for an ecologically wise and socially just world. These should be transformative alternatives to the currently dominant processes of globalized development, including its structural roots in modernity ${ }^{2}$, capitalism, state domination, patriarchy, and more specific phenomena, like casteism, found in some in parts of the world. Plus, they should go beyond the false solutions that those in power are proposing in an attempt to 'greenwash' development including variants of the 'green economy', market remedies and technofixes. The post-development agenda should investigate the what, how, who and why of all that is transformative, and what is not. Equally, though, proponents of post-development need to go beyond a number of weaknesses in their narrative, acknowledge that development as an idea has not been buried, sharpen their focus on the structural changes needed to deal with issues of inequity, injustice, deprivation, and ecological collapse. ${ }^{\mathrm{v}}$

The exploration of alternatives to development already finds concrete expression in a panoply of new or re-emerging concepts and practices such as buen vivir, degrowth, ecological swaraj, radical feminisms of various kinds, ubuntu, commoning, solidarity economy, food and energy sovereignty. These are perhaps the most visible examples of an emergent post-

2 Note that a critique of 'modernity' does not imply a rejection of all that is 'modern', nor an uncritical acceptance of all that is 'traditional'; we are well aware that traditional societies had (and have) many aspects of inequity and injustice, and that elements of what has emerged in contemporary times have been liberating for those previously suppressed. It is the hegemonising, unidirectional, western-centricism of modernity we are pointing to. 
developmentalist epistemic-political field towards a pluriverse ${ }^{3}$. These radical alternatives are becoming not only more visible but, increasingly, genuinely credible and viable. And yet they are still marginal in comparison to the dominant narrative and practice of development. Thus, it seems a good moment to make such alternatives more widely known, and to facilitate bridges amongst them while respecting their geopolitical and epistemic specificities. It is also critical to build bridges between constructive alternatives and peoples' movements resisting the dominant economic and political systems. ${ }^{\mathrm{vi}}$

The article is structured as follows. First, we present a critique of development in its recent reincarnations, like 'sustainable development' and the 'green economy', outlining the road from Stockholm 1972 to Rio+20, or the road from the critique to the defence of economic growth. Second, we introduce the origins and importance of transformative alternative worldviews and practices to development. Third, we outline the purpose and conceptualization of the PostDevelopment Dictionary, with a set of questions at the core of the agenda for transformation that we are proposing.

\section{Sustainable Development, the Green Economy and their false solutions}

"Everything must change in order to remain the same" Giuseppe Tomasi di Lampedusa, The Leopard (1963)

In 1987, the UN World Commission on Development and the Environment presented the report "Our common future" (better known as the Brundtland report), coining the concept sustainable development, then launched at the Rio summit on Environment and Development in 1992 (Principle 12 of the Declaration). Within such a framing, the push towards growth and economic liberalization was taken further at subsequent global events relating to sustainable development, though partially concealed behind the rhetoric of environmental sustainability. Compared to the United Nations Conference on Environment and Development in Stockholm 1972, the latter conferences involved an overall reframing of both the diagnosis and prognosis in relation to the ecological crisis (See Table 1). The focus supposedly became poverty in developing countries, instead of affluence in developed countries, along the lines of the post-materialist thesis of Inglehart ('you first need to be rich, in order to be an environmentalist'; critiqued by MartinezAlier). ${ }^{\text {vii }}$ In so doing, economic growth was freed of the stigma, and reframed as a necessary step

3 See Walter Mignolo, "On pluriversality”. Available at: http://waltermignolo.com/on-pluriversality/ (Accessed on 09/03/2017) 
towards the solution of environmental problems. ${ }^{\text {viii }}$ This watering down of the initial debates of 1970s influenced by the Limits to Growth report ${ }^{\mathrm{ix}}$ constitutes the core of the 'green economy', a kind of Green Keynesianism with new millennium proposals such as a Green New Deal, and the 2030 Agenda for Sustainable Development.

\begin{tabular}{|c|c|c|}
\hline $\begin{array}{l}\text { Prescription for the } \\
\text { environmental crisis }\end{array}$ & $\begin{array}{l}\text { Stockholm } 1972 \\
\text { Detailed enumeration of } \\
\text { biotic and physical } \\
\text { resources that should be } \\
\text { preserved. }\end{array}$ & $\begin{array}{l}\text { Rio } 1992 \\
\text { More abstract notion of } \\
\text { 'sustainable development'. }\end{array}$ \\
\hline $\begin{array}{l}\text { Causes of environmental } \\
\text { degradation }\end{array}$ & $\begin{array}{l}\text { Resource extraction and } \\
\text { existing relations of } \\
\text { economic exploitation. } \\
\text { Governments. }\end{array}$ & $\begin{array}{l}\text { Poverty in developing } \\
\text { countries. } \\
\text { - Private initiatives: } \\
\text { corporations and NGOs; } \\
\text { - Agenda } 21 \text { for } \\
\text { municipalities (the lowest } \\
\text { administration level). }\end{array}$ \\
\hline Instruments & $\begin{array}{l}\text { - Political demands; } \\
\text { - Territorial and resource } \\
\text { planning. }\end{array}$ & $\begin{array}{l}\text { - Legislation (e.g. } \\
\text { Environmental Impact } \\
\text { Assessment); } \\
\text { - Market instruments. }\end{array}$ \\
\hline
\end{tabular}

Table 1: A comparison of UN Environment Conferences: Stockholm 1972 and Rio 1992 ${ }^{x}$

At the UN Conference for Sustainable Development in 2012 (the so called Rio+20 Summit) the concept of 'green economy' played a key role as the guiding framework of the multilateral discussions (though resistance from many southern nations meant it was not as central as its proponents may have wished). In preparation for the summit, The United Nations Environmental Programme (UNEP) published a report on 'green economy', defining it "as one that results in improved human well-being and social equity, while significantly reducing environmental risks and ecological scarcities". ${ }^{x i}$ In consonance with the pro-growth approach of sustainable development, the report by-passed any trade-off between economic growth and environmental conservation, and conceptualized natural capital as a 'critical economic asset' opening the doors for commodification 
(so called green capitalism). In fact, it clearly stated that "the key aim for a transition to a green economy is to enable economic growth and investment while increasing environmental quality and social inclusiveness." $x i i$

In the Rio+20 final declaration, advocacy for economic growth is recalled in more than 20 articles. For example, Article 4 states that 'We also reaffirm the need to achieve sustainable development by: promoting sustained, inclusive and equitable economic growth'. This approach is based on neoclassical economic theory (environmental economics), leading to the belief that economic growth will de-link (or decouple) itself from its environmental base through dematerialization and de-pollution because of the improvement in eco-efficiency (increased resource productivity and decreased pollution). In this conceptual framework, market prices are considered the appropriate means for solving environmental issues and exogenous rates of technological progress are expected to counterbalance the effects of resource exhaustion. However, the conflict between a growth-dominated economy and environment cannot be solved with appeals to 'sustainable development', 'eco-efficiency', 'ecological modernisation', 'geo-engineering', 'smart agricultures' or 'cities', 'circular' or 'green economy'. These are false solutions.

For instance, while the Green Economy (GE) approach could be seen as an improvement over the conventional neoliberal economic model, it remains fundamentally flawed on a number of counts. For instance, the final objective for a New Green Deal is the creation of 'resilient low carbon economies, rich in jobs and based on independent sources of energy supply'. xiii While on this end there might general agreement, the controversy remains on the means to adopt. Among the flaws or weaknesses of the GE/SD approach as articulated thus far in various UN or UN sponsored documents, including the declaration for "Transforming our world: The 2030 Agenda for Sustainable Development", ${ }^{\text {xiv }}$ are the following: ${ }^{\mathrm{xv}}$

1. Absence of an analysis of the historical and structural roots of poverty, hunger, unsustainability and inequities, which include centralization of state power and capitalist monopolies;

2. Inadequate focus on direct democratic governance (decision-making by citizens and communities in face-to-face settings), beyond the stress on accountability and transparency;

3. Inability to recognize the biophysical limits to economic growth;

4. Continued subservience to private capital, and inability or unwillingness to democratise the economy;

5. Modern science and technology held up as panacea, ignoring their limits and marginalising other forms of knowledge; 
6. Culture, ethics and spirituality side-lined;

7. Unbridled consumerism not tackled head-on;

8. Global relations built on localization and self-reliance missing; and,

9. No new architecture of global governance, with a continued reliance on the centrality of nation-states, denying true democratisation.

These weaknesses outline why and how we consider the solutions that emerge out of SD and GE as false. In the next section we instead present the alternatives that go beyond development embedding a real potential for transformation.

\section{Transformative alternatives to development: Worldviews and practices}

\subsection{Critique of development and origins of alternatives worldviews}

A range of different and complementary notions or worldviews have emerged in various regions of the world, that seek to envision and achieve more fundamental transformation than that proposed by GE/SD approaches. Some of these are a revival of the long-standing worldviews of indigenous peoples; some have emerged from recent social and environmental movements in relation to old traditions and philosophies. Arising from different cultural and social contexts, they sometime differ on the prescription (what shall be done how), but they share the main characteristics of the diagnosis (what is the problem and who is responsible for it) as well as similar or equivalent Weltanschauungen (worldviews). The Post-Development Dictionary aims to illuminate pathways towards a synergic articulation of these alternatives to development. ${ }^{x v i}$

Unlike sustainable development, which is a concept based on false consensus, ${ }^{x v i i}$ these alternative approaches cannot be reduced to any single one and therefore do not aspire to be adopted as a common goal by the United Nations, the OECD or the African Union. These ideas are born as proposals for radical change from local to global. In a post-political condition, ${ }^{\text {xviii }}$ they intend to repoliticise the debate on the much-needed socio-ecological transformation, affirming dissidence with the current world representations and searching for alternative ones. Along these lines, they are a critique of the current development hegemony, meaning a critique of the homogenisation of cultures due to the widespread adoption of particular technologies and consumption and production models experienced in the global North. ${ }^{x i x}$ The Western development model is a mental construct adopted by the rest of the world that needs to be deconstructed. ${ }^{\mathrm{xx}}$ Development might thus be seen as a toxic term to be rejected, ${ }^{\mathrm{xxi}}$ and thus, 'sustainable development' as an oxymoron. 
Deconstructing development opens up the door for a multiplicity of new and old notions and worldviews, or else a matrix of alternatives. ${ }^{x i i}$ This includes Buen Vivir, a culture of life with different names and varieties in various regions of South America; Ubuntu with its emphasis on human mutuality in South Africa and several equivalents in other parts of Africa; Swaraj with a focus on self-reliance and self-governance, in India; and many others. ${ }^{x i i i}$ What is important is that while they are ancient, they are re-emerging in original or modified forms as a part of the narrative of movements that are struggling against development and/or asserting alternative forms of wellbeing. Ecofeminist arguments represent a further strand in this post-development rainbow. ${ }^{\text {xxiv }}$

These worldviews are not a novelty of the $21^{\text {th }}$ Century, but they are rather part of a long search for and practice of alternative ways of living forged in the furnace of humanity's struggle for emancipation and enlightenment within (rather than outside of) the womb of nature. What is remarkable about these alternative proposals, however, is that they often arise from traditionally marginalized groups. These worldviews are different from dominant Western ones as they emerge from non-capitalist communities or from non-capitalist spaces such as the household sector in the global North. ${ }^{\mathrm{xxv}}$ They are therefore independent of the anthropocentric and androcentric logic of capitalism, the dominant civilization, as well as with the various state socialist (effectively state capitalist) models existing until now. Other approaches emerging from within the (industrialised countries --- the belly of the beast, so to speak --- can also break from dominant logic, such as is the case with degrowth (an example of non-occidentalist west. ${ }^{\text {xxvi }}$

These worldviews differ sharply from today's notion of development. It is not about applying a set of policies, instruments and indicators to exit 'underdevelopment' and reach that desired condition of 'development'. In any case, how many countries have achieved development? Decades after the notion of 'development' was spread around the world, only a handful of countries can be called 'developed', others are struggling to emulate them, and all are doing this at enormous ecological and social cost. The problem is not in the lack of implementation, but rather in the concept of development as linear, unidirectional material and financial growth. The world experiences a widespread 'bad development', including those countries regarded as industrialized, i.e. countries whose lifestyle was to serve as a reference beacon for backward countries. The functioning of the global system is itself a 'bad developer'.

In short, it is urgent to dissolve the traditional concept of progress in its productivist drift and of development (as well as its many synonyms) as a unidirectional concept, especially in its 
mechanistic view of economic growth. However, it is not only about dissolving it; different views are required, much richer in content as well as in complexity. As Kallis explains:

"Sustainable development and its more recent reincarnation "green growth" depoliticize genuine political antagonisms between alternative visions for the future. They render environmental problems technical, promising win-win solutions and the impossible goal of perpetuating economic growth without harming the environment." ${ }^{x x v i i}$

Therefore, these alternative approaches are necessary to challenge the ideas of GE and SD and the associated belief in economic growth as a desirable path in political agendas. They are also important in presenting to us a set of ethical values and principles that underlie positive, transformative action, such as diversity, solidarity, commons, oneness with nature, interconnectedness, simplicity, inclusiveness, equity and non-hierarchy, pluriversality, and peace.

Hereafter we briefly describe two of these transformative alternatives coming from the contexts in which we, the authors, live: Ecological Swaraj (or Radical Ecological Democracy) from India and Degrowth from Europe.

\subsection{Ecological Swaraj or Radical Ecological Democracy}

Emerging from the grassroots experience of communities and civil society practicing or conceiving alternatives across the range of human endeavour in India, Ecological Swaraj (loosely, self-rule including self-reliance), or Radical Ecological Democracy (RED) is a framework that respects the limits of the Earth and the rights of other species, while pursuing the core values of social justice and equity. With its strong democratic and egalitarian impulse, it seeks to empower every person to be a part of decision-making, and its holistic vision of human well-being encompasses physical, material, socio-cultural, intellectual, and spiritual dimensions. ${ }^{\text {xxviii }}$ Rather than the state and the corporation, it puts collectives and communities at the centre of governance and the economy, an approach that is grounded in real-life initiatives across the Indian subcontinent (see www.alternativesindia.org).

This approach rests on the following intersecting spheres: ecological wisdom and sustainability, social well-being and justice, economic democracy, direct political democracy, and cultural diversity. Fundamental to it is a set of values that include diversity, autonomy, cooperation and 
solidarity, rights with responsibilities, equity and justice, inclusion, simplicity and sufficiency, respect for all life, non-violence, inter-connectedness, dignity of labour, and others.

Ecological Swaraj is an evolving approach, not a blueprint set in stone. In its very process of democratic grassroots evolution, it forms an alternative to top-down ideologies and formulations, even as it takes on board the relevant elements of such ideologies.

\subsection{Degrowth: Not less of the same, but simply different}

Degrowth calls for a rejection of the obsession with economic growth as a panacea for the solution of all problems. It should not be interpreted in its literal meaning (decrease of the Gross Domestic Product) because that phenomenon already has a name: it is called recession. Degrowth does not mean 'less of the same' but it is simply different. ${ }^{x x i x}$ It was born in the Global North, and it is being developed for that context, though the questioning of a one-way future consisting only of economic growth is also inspired by - and relevant for - the Global South. ${ }^{\mathrm{xx}}$

The term was proposed by political ecologist André Gorz in 1972. In Australia, Ted Trainer was urging the public to Abandon Affluence! in 1985; in Germany, ecofeminists Maria Mies and Veronica Bennholdt-Thomsen argued The Subsistence Perspective in 1993. ${ }^{\mathrm{xxi}}$ Other European environmental activists used Degrowth in 2001 as a provocative slogan or mot-obus, a missile word to re-politicize environmentalism. It springs from the hypothesis that we can live better with less and offers a frame that connects diverse ideas, concepts and proposals. . $^{\mathrm{xxii}}$

Generally, degrowth challenges the hegemony of growth and calls for a democratically led redistributive downscaling of production and consumption in industrialised countries as a means to achieve environmental sustainability, social justice and well-being. Degrowth is usually associated with the idea that smaller can be beautiful. However, the emphasis should not only be on "less", but also on "different". Degrowth signifies a society with a smaller metabolism (the energy and material throughput of the economy), but more importantly, a society with a metabolism which has a different structure and serves new functions. In a degrowth society everything will be different from the current mainstream: activities, forms and uses of energy, relations, gender roles, allocations of time between paid and non-paid work, and relations with the non-human world. 
Hereafter, we outline the purpose and conceptualization of The Post-Development Dictionary that aims to collect and articulate the transformative alternatives to (sustainable) development.

\section{The Post-Development Dictionary agenda: Towards the pluriverse}

At a time when neoliberal governments and rampant extractivism brutalise the every day life of citizens across the world and in particular the global South, it is crucial that oppositional voices and people's movements engage in a concentrated effort of research, outreach, dialogue, and action, informed by and informing grassroots practice. Resistance is crucial, but it is not enough. We need our own narratives. Acts of resistance and regeneration offer hope in the here and now. This is what The Post-Development Dictionary is all about. It is meant to be a process of research, writing and dialogue that will culminate in a comprehensive book in early 2018. The Dictionary format of the book, comprises a series of keyword entries, with one or more expert scholars or practitioners writing each. The book has three main sections: 1) Global Reflections on an Old Idea: Development; 2) False solutions; and 3) Transformative alternatives: worldviews and practices. It is co-edited by the two authors of this article in collaboration with Ariel Salleh, Arturo Escobar and Alberto Acosta.

In sum, the book aims to, first, present a rich variety of worldviews and practices relating to the collective search for an ecologically wise and socially just world, with well known ones like ecosocialism, Buen Vivir or ecofeminism, but also rarely-heard-of like kyosei, minobimaatisiiwin and Nayakrishi. A vast range of approaches of indigenous peoples, peasant and pastoral communities, peoples' movements, and urban communities are covered. It also offers critical essays on a number of false solutions that those in power are proposing in an attempt to 'greenwash' development, such as efficiency, techno-fixes, smart cities, life-boat ethics, (neo)extractivism, green economy and ecomodernism. Second, consolidate a 25 years long debate on the criticism and alternatives to development, beyond the current fragmentation, presenting both its state of the art and future challenges with contributions from influential international authors from different disciplines and continents. Third, be a guide to understand the most important concepts of post-development for readers interested in grasping its nuances, and along the way help to clarify and overcome common misunderstandings and criticisms, and provide a basis to further advance both intellectual research and political practice of the alternatives to development. And fourth, be a small but significant contribution to a world-wide confluence of alternative cultural, economic, social, political and ecological visions and practices. 


\section{Conclusions}

This article has attempted to briefly lay out both the critique of (sustainable) development as well as the potential and nuances of a post-development agenda. The Post-Development Dictionary is meant to deepen and widen a research, dialogue and action agenda for activists, policy makers and scholars on a variety of worldviews and practices relating to our collective search for an ecologically wise and socially just world. These are meant to be truly transformative, and may be distinguished from the false solutions in a number of ways. Firstly, their attempts to transform the structural roots of a problem, along political, economic, social, cultural, and ecological axes. Secondly, in their explicit or implicit questioning of the core assumptions of the development discourse (e.g., growth, material progress, instrumental rationality, the centrality of markets and economy, universality, modernity and its binaries, and so forth). Third, in encompassing a radically different set of ethics and values to those underpinning the current system, including diversity, solidarity, commons, oneness with nature, interconnectedness, simplicity, inclusiveness, equity, non-hierarchy, pluriversality, and peace.

In conclusion, these alternatives to development practices and worldviews intend to re-politicise the debate on the much-needed socio-ecological transformation, affirming dissidence with the current world representations (i.e. sustainable development) and searching for alternative ones. They highlight the necessity to overcome the modern ontology of one world and expand on the multiplicity of worlds possible. As Escobar argues: "The modern ontology presumes the existence of One World - a universe. This assumption is undermined by discussions in Transition Discourses, the buen vivir, and the rights of Nature. In emphasizing the profound relationality of all life, these newer tendencies show that there are indeed relational worldviews or ontologies for which the world is always multiple - a pluriverse. Relational ontologies are those that eschew the divisions between nature and culture, individual and community, and between us and them that are central to the modern ontology. Some of today's struggles could be seen as reflecting the defence and activation of relational communities and worldviews ... and as such they could be read as ontological struggles; they refer to a different way of imagining life, to an other mode of existence. They point towards the pluriverse; in the successful formula of the Zapatista, the pluriverse can be described as 'a world where many worlds fit'."xxxiii

Along these lines, The Post-Development Dictionary will hopefully be an exciting volume of essays on transformative alternatives to the currently dominant processes of globalized development, including its structural roots in modernity, capitalism, state domination, patriarchy, and other forces. The book is meant to help in the steps towards an equitable, just, and ecologically 
wise world. When the language in use is inadequate to articulate what begs to be articulated, then it is time for a new dictionary: The Post-Development Dictionary: An agenda towards the pluriverse.

\section{Bibliography}

D'Alisa, G., F. Demaria, and G. Kallis. Degrowth: A Vocabulary for a New Era, London: Routledge, 2014.

Dearden, Nick. 'Is development becoming a toxic term?' The Guardian, 22/01/2014, http://www.theguardian.com/global-development-professionals-network/2015/jan/22/developmenttoxic-term?CMP=share_btn_tw

Demaria, F., F. Schneider, F. Sekulova, and J. Martinez-Alier. 'What is degrowth? From an activist slogan to a social movement', Environmental Values 22 (2013): 191-215.

Escobar, A. Encountering Development, Princeton: Princeton University Press, 1995.

Escobar, A. Sustainability: Design for the pluriverse. Development 54(2) (2011): 137-140.

Escobar, A. Degrowth, postdevelopment, and transitions: a preliminary conversation. Sustainability Science 10(3) (2015): 451-462.

Gómez-Baggethun, E. and Naredo, J.M. In search of lost time: the rise and fall of limits to growth in international sustainability policy. Sustainability Science 10(3) (2015): 385-395

Gudynas, E. and Acosta, A. 'La renovación de la crítica al desarrollo y el buen vivir como alternativa'. Utopia y Praxis Latinoamerica 16(53) (2011): 71-83.

Gudynas, E. 'Buen vivir: today’s tomorrow'. Development 54(4) (2011): 441-447.

Hornborg, A. (2009) 'Zero-sum world', International Journal of Comparative Sociology 50(3-4): 237-262.

Inglehart, R. Culture Shift in Advanced Industrial Societies, Princeton: Princeton University Press, 1990.

Kallis, G. 'The Degrowth alternative', Great Transition Initiative, http://www.greattransition.org/publication/the-degrowth-alternative, 2015

Kothari, A. 'Missed Opportunity? Comments on two global reports for the post-2015 goals process', Pune: Kalpavriksh and ICCA Consortium, 2013. http://www.unngls.org/IMG/pdf/Kalpavriksh_and_ICCA_Consortium_-_Post-2015_reports_critique_-

_Ashish_Kothari_July_2013.pdf

Kothari, A. 'Radical ecological democracy: A way for India and beyond', Development, 57(1) (2014): 36-45. doi:10.1057/dev.2014.43

Kothari, Ashish, Demaria, Federico, and Acosta, Alberto Buen vivir, degrowth and ecological swaraj: alternatives to development and the green economy. Development 57(3) (2015): 362-375.

Latouche, S. (2009) Farewell to Growth. London: Polity.

Martinez-Alier, J. The Environmentalism of the Poor: A Study of Ecological Conflicts and Valuation. Cheltenham: Edward Elgar, 2002.

Meadows, D.H, D.L. Meadows, J. Randers, and W.W. Beherns III. The Limits to Growth, New York: Universe Books, 1972.

Metz, T. Ubuntu as a moral theory and human rights in South Africa. African Human Rights Law Journal 11(2) (2011): 532-559.

Mies, M. Patriarchy and Accumulation on a World Scale. London: Zed, 1986. 
Mies, M. and V. Bennholdt-Thomsen. The Subsistence Perspective. London: Zed, 1993.

NEF. A Green New Deal: Joined-up policies to solve the triple crunch of the credit crisis, climate change and high oil prices. Green New Deal Group, New Economics Foundation, 2008. Available at http://b.3cdn.net/nefoundation/8f737ea195fe56db2f_xbm6ihwb1.pdf.

Poerksen, U. Plastic Words: The Tyranny of a Modular Language. Penn State University Press, 2004.

Rahnema, M. and Bawtree, V. The Post-Development Reader. Zed Books, 1997.

Rist, G. The History of Development: From Western Origins to Global Faith, Expanded Edition, London: Zed Books, 2003.

Salleh, A. Ecofeminism as Politics. London: Zed Books / New York: Palgrave, 1997.

SDSN. An Action Agenda for Sustainable Development, Report for the Secretary General, Sustainable Development Solutions Network, 2013.

Shiva, V. Staying Alive: Women, Ecology and Development. London: Zed Books, 1989.

Sousa Santos, B. A Non-Occidentalist West? Learned Ignorance and Ecology of Knowledge. Theory, Culture and Society 26(7-8) (2009): 103-125.

Swyngedouw, E. 'Impossible/undesirable sustainability and the post-political Condition', in J.R. Krueger and D. Gibbs (eds.), The Sustainable Development Paradox, New York: Guilford Press, 2007: pp. 13-40.

Trainer, T. Abandon Affluence! London: Zed, 1985.

UNEP. Towards a Green Economy: Pathways to Sustainable Development and Poverty Eradication, A Synthesis for Policy Makers, Nairobi: United Nations Environment Programme, 2011, www.unep.org/greeneconomy

United Nations. A New Global Partnership: Eradicate Poverty and Transform Economies Through Sustainable Development, The Report of the High-Level Panel of Eminent Persons on the Post2015 Development Agenda. New York: United Nations, 2013.

United Nations. Transforming our World: The 2030 Agenda for Sustainable Development. New York: United Nations, 2015. Available at:

https://sustainabledevelopment.un.org/post2015/transformingourworld/publication

United Nations Secretary-General's High-level Panel on Global Sustainability. Resilient People, Resilient Planet: A future worth choosing, New York: United Nations, 2012.

Ziai, Aram. Post-development: Pre-mature burials and haunting ghosts, Development and Change 46(4) (2015): 833-854.

\footnotetext{
i Notes

Sachs, Development Dictionary

ii United Nations, Agenda

iii $\quad$ Sachs, Development Dictionary; Escobar, Encountering Development; Rist, History of Development; Rahnema and Bawtree, Post-Development Reader

iv Gudynas and Acosta, "La renovación", 75

v Ziai, "Post-development"

vi Kothari et al, "Buen vivir", 362-375

vii Inglehart, Culture Shift; Martinez-Alier, The Environmentalism

viii Gómez-Baggethun and Naredo, "In search of"
} 


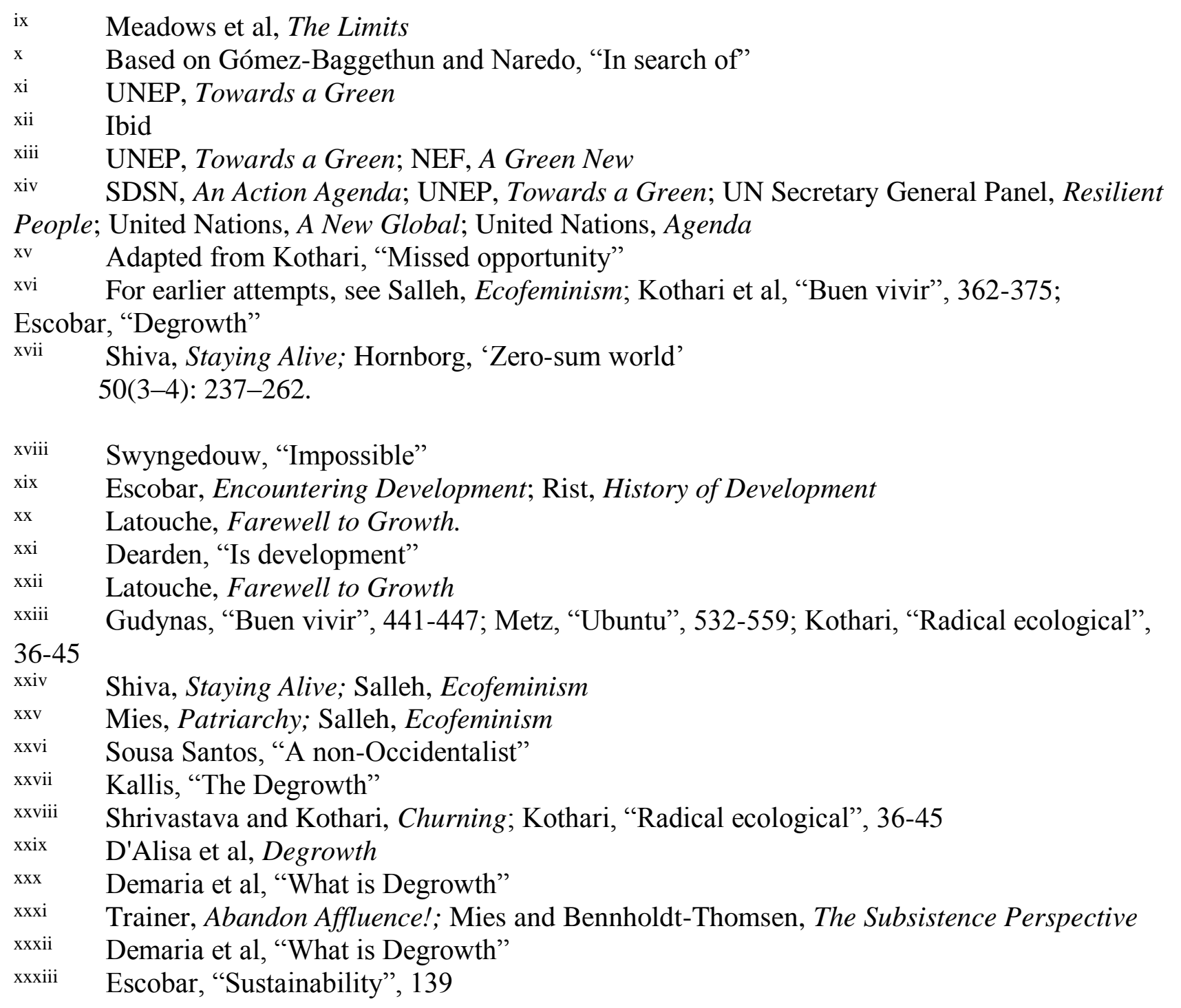

"This is an Accepted Manuscript of an article published by Taylor \& Francis in Third world quarterly on 16 Aug. 2071, available online: http://www.tandfonline.com/ article DOI $10.1080 / 01436597.2017 .1350821$ 